\title{
PENGARUH KEGIATAN EKSTRAKURIKULER ROHANI ISLAM (ROHIS) TERHADAP PRESTASI BELAJAR SISWA PADA MATA PELAJARAN PAI
}

\author{
Ade Nasihudin ${ }^{1}$, Sri Utami Dewi ${ }^{2}$ \\ IAILM Suryalaya Tasikmalaya ${ }^{1}$, IAIC Tasikmalaya ${ }^{2}$, Indonesia \\ anasihudin92@gmail.com¹, sriutami@iaic.ac.id ${ }^{2}$
}

\begin{abstract}
Abstrack
This study aims to determine the effect of extracurricular activities ROHIS (Rohani Islam) on student achievement in Islamic education subjects at SDN 3 Cinagara Malangbong Garut. The research method that I use is a descriptive method with a quantitative approach. The population in this study were all participants / members of ROHIS at SDN 3 Cinagara Garut, totaling 30 students, and with a total sample of 30. Based on the calculation of the correlation between variables $X$ and $Y$ using the Rank Sperman formula (rs) of 0.58. The spherical rank correlation number is in the interval 0.41-0.60. With enough qualifications. This means that there is sufficient influence between ROHIS extracurricular activities on learning achievement in Islamic Education subjects at SDN 3 Cinagara. And through hypothesis testing it is known that the correlation number is significant. Because proven_count is 5.52 and ttable is 2.048. By comparing the two numbers, it is proven that tcount is greater than ttable. This contains an interpretation that the data regarding the effect of ROHIS Extracurricular Activities on Learning Achievement in Islamic Education Subjects at SDN 3 Cinagara are significant. Thus it is concluded that the alternative hypothesis (Ha) is accepted and the null hypothesis (Ho) is rejected.
\end{abstract}

Keywords: Extracurricular Activities, achievements, learning, PAI

\begin{abstract}
Abstrak
Penelitian ini bertujuan untuk bagaimana pengaruh kegiatan ekstrakurikuler ROHIS (Rohani Islam) terhadap prestasi belajar siswa pada mata pelajaran PAI di SDN 3 Cinagara Malangbong Garut. Metode penelitian yang penulis gunakan adalah metode deskriptif dengan pendekatan kuantitatif. Populasi dalam penelitian ini adalah seluruh peserta/anggota ROHIS di SDN 3 Cinagara Garut yang berjumlah 30 peserta didik, dan dengan sampel seluruhnya yang berjumlah 30. Berdasarkan perhitungan korelasi antara variabel X dan Y yang menggunakan rumus Rank Sperman (rs) sebesar 0,58. Angka korelasi rank sperman tersebut berada pada interval 0,41-0,60. Dengan kualifikasi cukup. Artinya terdapat pengaruh cukup antara kegiatan ekstrakurikuler ROHIS terhadap prestasi belajara pada mata pelajaran PAI di SDN 3 Cinagara. Dan melalui uji hipotesis diketahui bahwa angka korelasi tersebut signifikan. Sebab terbukti sebesar 5,52 dan 2,048. Dengan membandingkan dua angka tersebut terbukti lebih besar daripada. Hal tersebut
\end{abstract}


mengandung interpretasi bahwa data mengenai Pengaruh Kegiatan Ekstrakurikuler ROHIS terhadap Prestasi Belajara pada Mata Pelajaran PAI di SDN 3 Cinagara tergolong signifikan. Dengan demikian disimpulkan bahwa hipotesis alternatif (Ha) diterima dan hipotesis nol (Ho) ditolak.

Kata Kunci: Kegiatan Ektra kurikuler, prestasi, belajar, PAI

\section{A. PENDAHULUAN}

Dalam pendidikan sekolah pendidikan agama diberikan berdasarkan kurikulum yang berlaku. Namun untuk sekolah umum, kurikulum pendidikan agama masih kurang memberikan materi keagamaan bagi siswa. Bahkan "di sekolah-sekolah swasta atau negri sejak dari pendidikan dasar sampai menengah atas, pendidikan agama islam (PAI) di laksanakan hanya satu kali dalam seminggu.

Bagaimana memberikan pendidikan agama islam dengan waktu yang di berikan hanya 1 kali dalam seminggu. sementara seorang siswa menghadapi suasana yang berbeda, bahkan cenderung berlawanan dengan nasehat-nasehat agama yang diterimanya sewaktu berada di sekolah. (Muhammad Kholid Fathoni, 2005:41).

Untuk itu kegiatan ekstrakurikuler juga diperlukan dalam pembelajaran PAI. Pembelajaran PAI yang banyak membahas tentang ilmu-ilmu agama Islam saat ini hanya sebatas pada pengetahuan namun siswa belum dapat memahami suatu ilmu dalam Pendidikan Agama Islam secara utuh. Serta siswa tidak dapat mengaplikasikan pengetahuan ilmu yang telah ia dapatkan di kelas pada kehidupan sehari-harinya. Maka dari itu, disinilah peran kegiatan ekstrakurikuler dalam membantu kegiatan intrakurikuler yang berupa pembelajaran di kelas untuk lebih memahami dan mengaplikasikan pengetahuan yang didapatkan siswa di kelas di kehidupan sehari-harinya.

Mengingat dalam intra kurikuler Pendidikan Agama Islam yang diajarkan di dalam kelas tidak cukup waktu, maka perlu tambahan melalui ekstra kurikuler/kegiatankegiatan keagamaan. Adapun kegiatan keagamaan yang ada di sekolah biasanya dilaksanakan oleh rohani islam (ROHIS) yang merupakan organisasi yang ada di sekolah. Yang memberikan suatu alternatif untuk melakukan bimbingan dan pelatihan mempelajari agama Islam. Bentuk kegiatan ini seperti, pelatihan alat-alat musik yang bernuansakan Islam, diskusi keagamaan, bakti sosial, peningkatan pengetahuan dan keterampilan keagamaan, peringatan hari besar Islam dan praktek-praktek keagamaan seperti sholat berjama'ah, shalat duha, dan kegiatan-kegiatan lainnya yang dapat menambah pengetahuan agama Islam, dan belum diajarkan di kelas, karena keterbatasan waktu sehingga penyampaian materi-materi juga terbatas.

Pada dasarnya penyelenggaraan ekstra kurikuler di sekolah bertujuan menggali dan memotivasi siswa-siswa pada bidang tertentu. Karena itu aktivitas ektrakurikuler harus disesuaikan dengan hobi dan kondisi siswa, sehingga melalui kegiatan tersebut siswa dapat memperjelas identitas dirinya. Sebagian pendidik memandang bahwa 
kegiatan tambahan itu merupakan sarana langsung untuk proses belajar mengajar, sehingga mereka memasukkannya dalam materi kurikulum yang akan diajarkan. Biasanya kegiatan ekstrakurikuler disusun bersamaan dengan penyusunan kisi-kisi kurikulum dan materi pelajaran. Itu artinya, kegiatan tersebut merupakan bagian dari pelajaran di sekolah dan kelulusan siswa pun dipengaruhi oleh aktivitasnya dalam kegiatan ekstrakurikuler tersebut. (Abdurrahman An-Nahlawi, 1995:187)

ROHIS mempunyai peran yang penting dalam kegiatan pengembangan dan bimbingan keagamaan yang dapat meningkatkan kompetensi agama Islam dan kualitas keimanan serta ketaqwaan siswa yang dapat diamalkan dalam kehidupan pribadi, baik di sekolah, rumah atau keluarga, maupun di masyarakat sekitar. (Abd Rahman AnNahlawi, 2012:28).

Namun demikian, kegiatan ekstra kurikuler ROHIS tidak serta merta menjadikan siswa memiliki pemahaman keagamaan yang mendalam, ada kalanya siswa yang mengikuti kegiatan keagamaan tersebut justru lemah dalam aspek kognitif, tapi bagus dalam afektif dan psikomotorik. Sebaliknya, adapula siswa yang memiliki nilai kognitif bagus, namun lemah dalam afektif dan psikomotorik. Hal ini tentu tidak sesuai dengan harapan diadakannya kegiatan ekstrakurikuler keagamaan. Karena sejatinya, kegiatan ekstra kurikuler keagamaan melahirkan pemahaman dan pengamalan siswa yang lebih baik terhadap nilai-nilai keagamaan sebagaimana yang termaktub dalam Peraturan Menteri Agama No 16 tahun 2010 pasal 10, bahwa pembelajaran ekstrakurikuler pendidikan agama bertujuan untuk memberikan pendalaman, penguatan, pembiasaan, serta perluasan dan pengembangan dari kegiatan intra kurikuler.

Di SDN 3 Cinagara terdapat serangkaian kegiatan ekstra kurikuler keagamaan (ROHIS) yang bertujuan untuk membentuk siswa menjadi manusia yang taat pada ajaran agama Islam. Dari hasil studi pendahuluan melalui wawancara dengan guru mata pelajaran Pendidikan Agama Islam (PAI) sekaligus sebagai pembina ekstra kulikuler ROHIS SDN 3 Cinagara, Ibu Popon Khodijah S.Pd.I, ditemukan informasi bahwa minat siswa untuk mengikuti kegiatan ekstra kurikuler keagamaan (ROHIS) di SDN 3 Cinagara sangat baik sedangkan prestasi belajar pada mata pelajaran PAI cenderung rendah. Padahal menurut beliau, kegiatan ekstra kurikuler ROHIS salah satunya adalah pemberian materi pembelajaran PAI yang sesuai dengan materi yang ada di kurikulum. Kegiatan ekstra kulikuler ini selalu berjalan dengan baik setiap minggunya, di mulai dari kegiatan berdo'a, membaca al-Quran kemudian dilanjutkan dengan kegiatan inti seperti pemberian materi PAI, mensyairkan sholawat Nabi dan lain sebagainya.

Rumusan masalah dari penelitian ini ialah bagaimana kegiatan ekstrakurikuler Rohani Islam (ROHIS) di SDN 3 Cinagara Malangbong Garut, bagaimana Prestasi belajar siswa pada mata pelajaran PAI di SDN 3 Cinagara Malangbong Garut dan agaimana pengaruh kegiatan ekstrakurikuler ROHIS (Rohani Islam) terhadap prestasi belajar siswa pada mata pelajaran PAI di SDN 3 Cinagara Malangbong Garut. Penelitian ini bertujuan untuk mengetahui kegiatan ekstrakurikuler Rohani Islam (ROHIS) di SDN 3 Cinagara Malangbong Garut, untuk mengetahui prestasi belajar siswa pada mata pelajaran PAI di SDN 3 Cinagara Malangbong Garut dan untuk mengetahui bagaimana pengaruh kegiatan ekstrakurikuler ROHIS (Rohani Islam) terhadap prestasi belajar 
siswa pada mata pelajaran PAI di SDN 3 Cinagara Malangbong Garut. Manfaat secara teoritis, diharapkan hasil penelitian ini dapat memberikan sumbangan ilmiah bagi pengembangan ilmu pengetahuan, terutama dalam kajian kegiatan ekstarakurukuler ROHIS. Secara praktis diharapkan bermanfaat bagi peserta didik, guru, sekolah, dan peneliti.

\section{Ekstrakurikuler Rohani Islam (ROHIS)}

Pengertian ekstrakurikuler menurut Kamus Besar Bahasa Indonesia (2014:291) yaitu:"suatu kegiatan yang berada di luar program yang tertulis di dalam kurikulum seperti latihan kepemimpinan dan pembinaan siswa". Sedangkan pengertian ROHIS menurut Departemen Pendidikan Nasional (2008 :1179) yang dikutip dari Kamus Besar Bahasa Indonesia adalah kepanjangan dari dua kata, yaitu Rohani dan Islam. Dalam Kamus Besar Bahasa Indonesia rohani yaitu yang bertalian atau berkenaan dengan roh, sedangkan roh yaitu sesuatu yang ada dalam jasad yang diciptakan Tuhan sebagai penyebab adanya hidup (kehidupan), jika sudah berpisah dari badan, berakhirlah kehidupan seseorang. Atau makhluk hidup yang tidak berjasad, tetapi berpikiran dan berperasaan.

Dari berbagai pendekatan istilah/pengertian di atas Ekstra kulikuler Rohani Islam (ROHIS) mempunyai arti sebuah program ekstra kurikuler yang kegiatannya terfokus kepada peningkatan pengetahuan, pemahaman, keterampilan dan sikap berbasis ke-Islaman yang pada akhirnya dapat mengantarkan siswa menjadi generasi mandiri berakhlak mulia.

Indikator ekstra kurikuler ROHIS antara lain sebagai berikut :

a. Memberikan wawasan akademik maupun non akademik

b. Membentuk karakter dan sikap siswa

c. Megembangkan minat dan bakat siswa (Peraturan Direktorat Jendral Agama Islam, 2009)

2. Prestasi Belajar

Kata prestasi belajar berasal dari dua suku kata, yaitu "prestasi" dan "belajar". Di dalam Kamus Besar Bahasa Indonesia, yang dimaksud dengan prestasi adalah: "Hasil yang telah dicapai (dari yang telah dilakukan, dikerjakan, dan sebagainya).”. (Departemen Pendidikan Nasional, 2008:1101).

Dalam perspektif psikologis, menurut Tohirin (2005:59) belajar merupakan suatu proses perubahan, yaitu perubahan dalam perilaku sebagai hasil dari interaksi dengan lingkungannya dalam memenuhi kebutuhan hidupnya. Menurut Sardiman menyatakan bahwa belajar merupakan suatu perubahan tingkah laku atau penampilan, dengan serangkaian kegiatan seperti dengan membaca, mengamati, mendengarkan, meniru dan lain sebagainya.

Berdasarkan definisi yang dikemukakan di atas, maka penulis mengambil kesimpulan bahwa prestasi belajar adalah hasil belajar yang telah dicapai oleh seorang siswa setelah melakukan kegiatan belajar tertentu yang ditunjukkan dengan 
nilai tes yang diberikan oleh guru setelah mengikuti tes-tes tertentu tentang apa yang telah dipelajari.

Indikator prestasi belajar antara lain sebagai berikut :
a. Kognitif
b. Afektif
c. Psikomotorik ( Berdasarkan nilai raport) (Nana Sudjana, 2001).

\section{B. METODE}

Metode penelitian yang digunakan adalah metode deskriptif dengan pendekatan kuantitatif, teknik sampling yang digunakan adalah total sampling yang melibatkan seluruh peserta atau anggota ROHIS yang berjumlah 30 orang. Untuk pengumpulan data, peneliti menggunakan tiga teknik yaitu observasi, angket dan wawancara. Untuk angket, peserta didik diberikan lembar pertanyaan yang memuat sepuluh pertanyaan dari setiap variabel, yakni variabel x (kegiatan ekstrakurikuler) dan variabel y (prestasi belajar). Pertanyaan-pertanyaan angket dibuat berdasarkan dimensi dari komunikasi guru dalam pembelajaran dan perhatian peserta didik kemudian diuraikan menjadi beberapa indikator. Selanjutnya dilakukan analisis variabel untuk mengetahui hasil statistik dari data penelitian. Kemudian dilakukan analisis korelasi untuk menghitung korelasi variabel $\mathrm{x}$ dan variabel $\mathrm{y}$. Dalam analisis korelasi metode yang digunakan adalah metode rank spearman.

\section{HASIL DAN PEMBAHASAN}

Data yang dikumpulkan dilakukan dengan skala pengukuran ordinal, maka statistik uji yang dianggap paling cocok adalah dengan menggunakan koefisien korelasi rank spearman (rs). Adapun operasi perhitungannya dimulai dari rumus rank spearman setelah melalui beberapa tahap yaitu :

1. Menghitung korelasi antara variabel $\mathrm{X}$ dengan variabel $\mathrm{Y}$ dengan menggunakan rumus rank sperman (rs) :

$$
\begin{aligned}
& r s=\frac{1-6 \sum d i^{2}}{N^{3}-N} \\
& =1-\frac{6.1927,88}{26970} \\
& =1-\frac{11567,28}{26970} \\
& =1-0,42 \\
& =0,58
\end{aligned}
$$

2. Mengkonfirmasi nilai rs pada skala Guilgord
$0,00-0,20$
$0,21-0,40$
$\longrightarrow$ Very low
$0,41-0,60$ Low
Moderate 


$$
\begin{aligned}
& 0,61-0,80 \longrightarrow \text { High } \\
& 0,81-1,00 \longrightarrow \text { Very high }
\end{aligned}
$$

Dari skala Guilford diatas, maka dapat diketahui bahwa tingkat koefisien korelasi adalah 0,58. Hal ini memberikan makna bahwa antara variabel $\mathrm{X}$ yaitu Pengaruh kegiatan ekstra kurikuler ROHIS dengan Variabel Y yaitu prestasi belajar pada mata pelajaran PAI terdapat korelasi positif dengan tingkat korelasi cukup, karena angka tersebut berada pada interval 0,41-0,60

3. Menentukan Derajat Detreminasi

Untuk mengetahui besarnya pengaruh antara Variabel $\mathrm{X}$ yaitu dengan Variabel Y prestasi belajar pada mata pelajaran PAI dapat diketahui melalui uji detreminasi sebagai berikut :

$$
\begin{aligned}
\mathrm{D} & =\mathrm{rs}^{2} \times 100 \% \\
& =(0,58)^{2} \times 100 \% \\
& =0,33 \times 100 \% \\
& =33 \%
\end{aligned}
$$

Hasil penghitungan diatas menunjukan bahwa Pengaruh Kegiatan Ekstra kurikuler ROHIS terhadap Prestasi Belajar pada Mata Pelajaran PAI 33\% Sedangkan faktor lain mencapai $67 \%$. Hal ini menunjukan bahwa masih ada faktor-faktor lain yang bisa mempengaruhi prestasi belajar pada mata pelajaran PAI di SDN 3 Cinagara.

4. Menguji Hipotesis

Uji hipotesis digunakan untuk mengetahui angka korelasi yang ditunjukan oleh hasil hitung diatas tergolong meyakinkan kebenarannya atau tidak. Kriterianya adalah jika terbukti $t_{\text {hitung }}$ lebih besar daripada $t_{\text {tabel }}$ maka data tergolong memiliki korelasi yang signifikan. Adapun jika $t_{\text {tabel }}$ lebih kecil atau sama dengan anka $t_{\text {tabel }}$ maka data korelasi tidak signifikan. Untuk menentukannya dilakukan dengan proses penghitungan sebagai berikut:

a) Menentukan $t_{\text {hitung }}$

$$
\begin{aligned}
t_{\text {hitung }}= & r s \frac{\sqrt{n-2}}{1-r s^{2}} \\
& =0,33 \frac{\sqrt{30-2}}{1-\left(0,67^{2}\right)} \\
& =0,33 \frac{\sqrt{28}}{0,44} \\
& =0,33 \sqrt{63,64} \\
& =0,33(7,97) \\
& =5,52
\end{aligned}
$$

b) Menentukan $t_{\text {tabel }}$

$$
\begin{aligned}
t_{\text {tabel }}= & \mathrm{t}(1-\mathrm{a})(\mathrm{dk}) \\
& =\mathrm{t}(1-\mathrm{a})(\mathrm{n}-2) \\
& =\mathrm{t}(1-0,5)(30-2) \\
& =(0,95)(28) \\
& =2,048
\end{aligned}
$$




\section{c) Penginterpretasikan Hsil Hitung $t$}

Diketahuit $_{\text {hitung }}$ sebesar 5,52 dan $t_{\text {tabel }} 2,048$. Dengan membandingkan dua angka tersebut terbukti $t_{\text {hitung }}$ lebih besar daripada $t_{\text {tabel }}$. Hal tersebut mengandung interpretasi bahwa data mengenai Pengaruh Kegiatan Ekstra kurikuler ROHIS terhadap Prestasi Belajar pada Mata Pelajaran PAI di SDN 3 Cinagara tergolong signifikan. Dengan demikian disimpulkan bahwa hipotesis alternatif $(\mathrm{Ha})$ diterima dan hipotesis nol (Ho) ditolak.

Hasil dari deskripsi penelitian dan hasil analisis data, dapat dijabarkan sebagai berikut :

Kegiatan ekstrakurikuler ROHIS di SDN 3 Cinagara tergolong cukup. Hal ini berdasarkan pada hasil penelitian yang dilakukan kepada 30 responden (santri) dengan menggunakan angket, kemudian dihitung dengan skala penafsirannya dengan memperoleh rata- rata sebesar 36,5 berada pada klasifikasi cukup, kegiatan ekstrakurikuler ROHIS di SDN 3 masih terbilang cukup dan masih ada faktor-faktor lain dari kegiatan ekstrakurikuler ROHIS di SDN 3 tersebut, dengan interval antara 35,94-38,91, artinya bahwa sebagian indikator Variabel X terpenuhi.

Prestasi belajar pada Mata Pelajaran PAI tergolong kurang. Hal ini berdasarkan pada hasil penelitian yang dilakukan kepada 30 responden (santri) dengan menggunakan angket ,kemudian dihitung berdasarkan skala penafsiran rata-rata hitung 26,8 berada pada klasifikasi kurang, dengan interval antara 24,8-29,6 .Hal ini berarti indikator variable Y tidak terpenuhi.

Pengaruh kegiatan ekstrakurikuler ROHIS terhadap prestasi belajar siswa berdasarkan perhitungan korelasi antara variabel $\mathrm{X}$ dan $\mathrm{Y}$ yang menggunakan rumus Rank Sperman (rs) sebesar 0,58. Angka korelasi rank sperman tersebut berada pada interval 0,41-0,60. Dengan kualifikasi cukup. Artinya terdapat pengaruh cukup Kegiatan Ekstrakurikuler ROHIS terhadap Prestasi Belajara pada Mata Pelajaran PAI di SDN 3 Cinagara. Melalui uji hipotesis diketahui bahwa angka korelasi tersebut signifikan. Sebab terbuktit $t_{\text {hitung }}$ sebesar 5,52 dant $t_{\text {tabel }}$ 2,048. Dengan membandingkan dua angka tersebut terbukti $t_{\text {hitung }}$ lebih besar daripadat $t_{\text {tabel. }}$. Hal tersebut mengandung interpretasi bahwa data mengenai Pengaruh Kegiatan Ekstrakurikuler ROHIS terhadap Prestasi Belajara pada Mata Pelajaran PAI di SDN 3 Cinagara tergolong signifikan. Dengan demikian disimpulkan bahwa hipotesis alternatif (Ha) diterima dan hipotesis nol (Ho) ditolak.

\section{SIMPULAN}

1. Simpulan

Berdasarkan hasil penelitian yang penulis lakukan tentang Pengaruh Kegiatan Ekstrakurikuler ROHIS terhadap Prestasi Belajara pada Mata Pelajaran PAI di SDN 3 Cinagara, maka dapat diambil beberapa kesimpulan sebagai berikut :

a. Kegiatan Ekstrakurikuler ROHIS

Kegiatan ekstrakurikuler ROHIS di SDN 3 Cinagara tergolong cukup. Hal ini berdasarkan pada hasil penelitian yang dilakukan kepada 30 responden 
(santri) dengan menggunakan angket, kemudian dihitung dengan skala penafsirannya dengan memperoleh rata- rata sebesar 36,5 dengan interval antara 35,94-38,91, artinya bahwa sebagian indikatorVariabel X terpenuhi.

b. Prestasi Belajar pada Mata Pelajaran PAI

Prestasi belajar pada Mata Pelajaran PAI tergolong kurang. Hal ini berdasarkan pada hasil penelitian yang dilakukan kepada 30 responden (santri) dengan menggunakan angket ,kemudian dihitung berdasarkan skala penafsiran rata-rata hitung 26,8 berada pada klasifikasi kurang, dengan interval antara 24,829,6 .Hal ini berarti indikator variabel Y tidak terpenuhi.

c. Pengaruh Kegiatan Ekstrakurikuler ROHIS terhadap Prestasi Belajara pada Mata Pelajaran PAI

Berdasarkan perhitungan korelasi antara variabel $\mathrm{X}$ dan $\mathrm{Y}$ yang menggunakan rumus Rank Sperman (rs) sebesar 0,58. Angka korelasi rank sperman tersebut berada pada interval 0,41-0,60. Dengan kualifikasi cukup. Artinya terdapat pengaruh cukup antara kegiatan ekstrakurikuler ROHIS terhadap prestasi belajara pada mata pelajaran PAI di SDN 3 Cinagara. Dan melalui uji hipotesis diketahui bahwa angka korelasi tersebut signifikan. Sebab terbuktit $_{\text {hitung }}$ sebesar 5,52 dant tabel 2,048. Dengan membandingkan dua angka tersebut terbukti $t_{\text {hitung }}$ lebih besar daripadat $t_{\text {tabel }}$. Hal tersebut mengandung interpretasi bahwa data mengenai Pengaruh Kegiatan Ekstrakurikuler ROHIS terhadap Prestasi Belajara pada Mata Pelajaran PAI di SDN 3 Cinagara tergolong signifikan. Dengan demikian disimpulkan bahwa hipotesis alternatif (Ha) diterima dan hipotesis nol (Ho) ditolak.

\section{DAFTAR PUSTAKA}

Abd Rahman. 2012. Paradigma Baru Pembelajaran Pendidikan Agama Islam (PAI) Di Sekolah. Jakarta: Faris2 - UIN Jakarta, 2012.

Departemen Pendidikan Nasional. 2008. Kamus Besar Bahasa Indonesia, jilid IV, (Jakarta: PT Gramedia Pustaka Utama.

Fadhilah Suralaga, dkk. 2005. Psikologi Pendidikan Dalam Perspektif Islam. Jakarta: UIN Jakarta Press.

Haidar Putra Daulay. Pendidikan Islam :dalam Sistem Pendidikan Nasional di Indonesia. Jakarta. Kencana.

Hasbullah. 1996. Kapita Selekta Pendidikan Islam. Jakarta. Raja Grafindo Persada.

http://eka-yanuarti.blogspot.co.id/2010/12/ekstrakurikuler-rohis 8926.html

Muhaimin. 2001. Paradigma Pendidikan Islam (Upaya Mengefektifkan PAI di Sekolah). Bandung. Remaja Rosda Karya.

Muhammad Kholid Fathoni. 2005. Pendidikan Islam Dan Pendidikan Nasional (Paradigma Baru). Jakarta. Departemen Agama RI.

Nana Sudjana. 2001. Dasar-Dasar Proses Belajar Mengajar. Bandung. Sinar Baru Algensindo. 2001. 
Sugiyono, 2015. Metode Penelitian Pendidikan Pendekatan Kuantitatif, Kualitatif, $R \& D$. Bandung. Alfabeta.

Syaidin. 2005. Aplikasi Metode Qurani Dalam Pembelajaran Agama di Sekolah. Tasikmalaya, Pondok Pesantren Suryalaya Tasikmalaya.

Syofian Siregar, Statistik Parametrik untuk Penelitian Kuantitatif, (Jakarta: Bumi Aksara, 2014),

Tohirin, 2005. Psikologi Pembelajaran Pendidikan Agama Islam (Berbasis Integrasi dan Kompetensi). Jakarta. Rajagrafindo Persada.

Wawan. 2015. Pengantar Statistika Pendidikan. Tasikmalaya. Latifah Press.

Munir Ahmad. 2004. Mengungkap Pesan Al-Qur'an Tentang Pendidikan. Bandung. 